\title{
Gümüşhane ve Civarındaki Güncel Deprem Aktivitesinin Bölgesel ve Zamana Bağlı Değișimleri: İstatistiksel Bir Değerlendirme
}

\author{
Serkan ÖZTÜRK* \\ Gümüşhane Üniversitesi Mühendislik ve Doğa Bilimleri Fakültesi, Jeofizik Mühendisliği Bölümü, 29100, Gümüşhane \\ Geliş tarihi/Received 22.08 .2016 \\ Düzeltilerek geliş tarihi/Received in revised form 13.12.2016 \\ Kabul tarihi/Accepted 20.12.2016
}

$\ddot{O} z$

Bu çalışmada, Gümüşhane ve civarındaki deprem aktivitesinin bölgesel ve zamana bağlı değisşimlerinin istatistiksel bir analizi yapılmış ve güncel deprem karakteristikleri tespit edilmeye çalışılmışıtır. İstatistiksel analizler için, 21 Eylül 1970-26 Haziran 2016 yllları arasında süre magnitüdü $M_{D} \geq 1.1$ olan ve 2500 depremi içeren yaklaşık 45.76 ylllk bir deprem kataloğu kullanılmıştır. Bununla birlikte, standart normal sapma Z-değerinin hesabı için $M_{D} \geq 2.8$ olan ve 1336 depremi içeren ayrıştırılmış deprem kataloğu kullanılmıştır. Deprem büyüklükleri genellikle 2.5-3.5 arasında değişim gösterirken $M_{D}=2.8$ değerinde bir maksimuma ulaşmıştır. 2011 yllına kadar deprem sayllarında gözlenen sistematik artış 2011 yllından sonra bir azalım sürecine girmiştir. Çalışma alanı için tamlı magnitüdü $M c=2.8$ olarak alınmış ve b-değeri $1.01 \pm 0.02$ olarak hesaplanmıştır. Gümüşhane ve civarındaki depremlerin magnitüd-frekans dağılımı genel olarak $b=1.0$ ile verilen değerle iyi temsil edilir. 1970-2016 yılları arasindaki bölge için büyük sayllabilecek bazı depremlerden önce b-değerinde önemli düşüsller gözlenmekle birlikte son yıllarda önemli bir azalım gözlenmemiştir. Bölgesel ölçekte düşük b-değerleri, Kelkit ve Köse'yi içine alan doğu ve kuzey doğu kısımlar ile Köse'nin kuzeyinde ve Kelkit'in güneyinde gözlenmiştir. Düşük b-değerlerinin gözlendiği bu bölgeler gelecekteki olası deprem potansiyeli açısından önemli olabilir. Depremlerin tekrarlama zamanları ve ylllk olasılıkları üzerine yapllan analizler, Gümüşhane ve civarının büyük sayllabilecek deprem oluşumları açısından önemli bir deprem potansiyeline sahip olmadığın göstermektedir. Depremsellik oran değiş̧imlerine bağl olarak, 2016 yll ortalarında herhangi bir sismik durgunluk anomalisi gözlenmemişstir. Sonuç olarak istatistiksel değerlendirmeler, Gümüş̧ane sinırları içerisinde kısa vadede önemli bir deprem tehlikesi potansiyelinin olmadı̆̆ını ortaya koyar.

Anahtar kelimeler: b-değeri, Depremsellik, Gümüşhane, Tamlık magnitüdü, Z-değeri

\section{Regional and Temporal Variations of Current Earthquake Activity in and around Gümüşhane: A Statistical Assessment}

\begin{abstract}
In this study, a statistical analysis of regional and temporal changes of earthquake activity in and around Gümüşhane is made and the current earthquake characteristics are tried to identify. For the statistical analyses, a catalog about 45.76 years including 2500 earthquakes with the duration magnitude $M_{D} \geq 1.1$ between September 21, 1970 and July 26, 2016 is used. At the same time, declustered earthquake catalog including 1336 earthquakes with $M_{D} \geq 2.8$ is used for the
\end{abstract}

\footnotetext{
* Serkan ÖZTÜRK, serkanozturk@gumushane.edu.tr, Tel: (0456) 2337425
} 
calculation of standard normal deviate Z-value. Earthquake magnitudes generally changes between 2.5 and 3.5 while they reach a maximum in $M_{D}=2.8$. Systematic increase in the earthquake numbers until 2011 shows a decreasing trend after 2011. For the study region, completeness magnitude is taken as $M c=2.8$ and $b$-value is estimated as $1.01 \pm 0.02$. The frequencymagnitude distribution of earthquakes in and around Gümüşhane is well represented with $a b$ value typically close to 1.0. Although important decreases in b-values before some strong earthquakes in the region between 1970 and 2016 are observed, a significant decrease is not observed in recent years. Small b-values in regional scale are observed in the east and northeast parts including Kelkit and Köse with in the north of Köse and in the south of Kelkit. These regions in which low b-values are observed may be important in terms of the future possible earthquake potential. Analyses on the recurrence times and annual probabilities of earthquakes show that Gümüşhane and vicinity have not a significant earthquake potential with regard to occurrences of strong earthquakes. Depending on the seismicity rate changes, any seismic quiescence anomalies are not observed in the mid-2016. Consequently, statistical assessments reveal that there is not an important earthquake hazard potential within the boundary of Gümüşhane in the short-term.

Keywords: b-value, Seismicity, Gümüşhane, Completeness magnitude, Z-value

\section{Giriş}

Son y1llarda Türkiye'nin ve dünyanın farklı bölgeleri için deprem aktivitelerinin bölgesel ve zamana bağlı değişimleri, istatistiksel ve fiziksel olarak birçok araştırmacı tarafından analiz edilmiş ve birçok önemli sonuç ortaya konulmuştur (örneğin, Frohlich ve Davis, 1993, Wiemer ve Wyss, 2000, Awad vd., 2005, Öncel ve Wilson, 2007, Polat vd., 2008, Öztürk vd., 2008, Öztürk, 2011, 2014, 2015a,b, Öztürk ve Bayrak, 2012, Öztürk ve Sar1, 2013, Ormeni vd., 2016). Bu araştırmacılar, depremselliğin bölgesel ve zamana bağlı fiziksel davranışlarını tanımlayabilmek için sismolojik ölçekleme yasalarını kullanan birçok istatistiksel model önermişlerdir. $\mathrm{Bu}$ çalışma kapsamında kullanılan temel sismotektonik ölçekleme parametreleri ise: (i) depremlerin güç-yasası dağılımını tanımlayan $b$-değeri, depremsellik oran değişimlerinin analizinde kullanılan standart sapma Z-değeri olarak verilebilir. Ayrıca, $b$-değeri ve $Z$-değerinin bölgesel ve zamana bağlı değişimleri, tamlık magntüdü $M c$-değeri, deprem aktivitesinin bölge-zaman-magnitüd dağılımları ile bir bölgedeki farklı magnitüd seviyeleri için depremlerin tekrarlama zamanı ve yıllık olasılıklarının hesaplanmasi, deprem aktivitesinin davranışlarının anlaşılması açısından önemli sonuçlar ortaya koyar. $b$-değeri Gutenberg-Richter ilişkisinden (Gutenberg ve Richter, 1944) elde edilir ve sismolojide en iyi bilinen deneysel ilişskilerden biridir. $b$-değerinin tahmini, depremlerin frekansı ile sismik moment, enerji ve fay uzunluğu arasında bir ilişki ortaya koyar. $b$-değeri yalnızca bir bölgedeki büyük ve küçük depremlerin sayılarının kısmi oranlarını yansıtmaz aynı zamanda bölgedeki gerilme koşullarıyla da ilişkilidir. Sonuç olarak $b$-değeri, depremlerin boyut ölçeklendirme davranışını tanımlayan ve en yaygın olarak kullanılan depremsellik parametrelerinden biridir. Dünyanın birçok bölgesinde sismik durgunluk üzerine yapılan çok sayıdaki araştırma, verilen bir bölgedeki öncü anomalileri tespit edebilmek amaciyla yapılmaktadır. Depremsellik oranının istatistiksel olarak önemli bir azalımı öncü sismik durgunluk olarak tanımlanır (Wiemer ve Wyss, 1994) ve öncü durgunluk olgusunu içeren bölge-zaman depremsellik oluşumları, depremlere neden olabilen sismotektonik süreçlerle ilişkili olabilir. Dolayısıyla, sismotektonik parametreler arasındaki ilişkilerin potansiyel bölge-zaman analizleri, deprem karakteristiklerinin tanımlanmasında önemli katkılar sağlayabilir.

$\mathrm{Bu}$ çalışmada kapsamında, Gümüşhane ve civarındaki güncel deprem aktivitesinin istatistiksel bir değerlendirmesi yapılmıştır. $\mathrm{Bu}$ amaçla, sismotektonik $b$ ve $Z$-değeri ile 
$M c$-değerinin bölgesel ve zaman bağl1 değişimleri haritalanmış, depremselliğin bölge-zaman-magnitüd dağılımları analiz edilmiş, deprem oluşumlarının tekrarlama zamanları ile yıllık oluşma olasılıkları hesaplanmıştır. Sonuçta, Gümüşhane ve civarındaki güncel sismik aktivite, deprem tehlikesi açısından bölgesel ve zamana bağlı olarak değerlendirilmiştir.

\section{Gümüşhane ve Civarının Jeolojik- Tektonik Yapısı ve Depremselliği}

Gümüşhane, Kuzeydoğu Türkiye'de pontid Orojenik kuşağının doğusunda ve genellikle çökel tipinde kayaçların yüzeylendiği doğu Pontid tektonik birliğinin güney zonunda yer alır (Taş vd., 2003). Bölgenin taban kayaçları Paleozoyik yaşlı metamorfik kayaçlar ile bunları keserek yükselen Gümüşhane granitlerden oluşur. Genel olarak metamorfik kayaçlar ve granitlerle bilinen Paleozoyik dönemin ardından Mesozoyik dönemde denizel ortamlarda birikmiş formasyonlarda belirgindir. Denizel ortamda çökelmiş bu birimler başlıca kömür ara katmanlı çakıl taşı, kumtaş1, kireçtaş1, marn ve kil taşlarından oluşan tortul kayaç ve andezit, bazalt ve piroklastiklerden oluşan volkanik kökenli kayaçlardan oluşur (Taş vd., 2003). Birçok araştırmacı Jura döneminde oluşan bu kayaç topluluklarının yaklaşık doğu-batı yönünde uzanan bir rift havzasında biriktiğini ifade etmiştir.

Gümüşhane tektonik ve depremsellik açısından Türkiye'nin en sakin bölgelerinden biridir ve aktivitesi yüksek fay hatları bulunmamaktadır. Buna karşın, yaklaşık 80 $\mathrm{km}$ güneyden geçen ve Türkiye'nin en aktif doğrultu atımlı fay zonlarından biri olan Kuzey Anadolu Fay Zonuna (KAFZ) olan yakınlığı nedeniyle bu zon üzerinde meydana gelebilecek büyük depremlerden etkilenme potansiyeli olan bir bölgedir. Özellikle Harşit çayı boyunca dere yataklarındaki alüvyon zeminler üzerine inşa edilmiş olan yüksek katlı yapılar, KAFZ üzerinde meydana gelebilecek olası bir büyük depremden etkilenecektir. Gümüşhane ve civanının güncel sismotektonik konumunu kazanmasında etkili olan faktörler başlıca kırık sistemleri ve kıvrım tektoniğidir. Kırık zonları genellikle KAFZ'ye yakın bölgelerde olup genellikle normal, ters ve doğrultu atımlı faylardan oluşur. Kıvrımlı yapılar genellikle asimetrik antiklinal ve senklinallerden meydana gelmiştir (Taş vd., 2003).

KAFZ dünyada en iyi bilinen sağ yönlü doğrultu atımlı faylardan birisidir. $\mathrm{Bu}$ transform fay zonu doğuya doğru Kuzey Anadolu ile Doğu Anadolu arasında bir sınır oluşturur ve jeodezik verilere göre 24$30 \mathrm{~mm} /$ yıllık sağ yönlü bir hareket sergiler (Reilinger vd., 1997). KAFZ, tek bir kırık düzlemi olmayıp birbirine paralel veya kademeli faylardan oluşan bir fay zonu durumundadır. Gümüşhane ve civarının ana tektonik yapısı Şaraoğlu vd. (1992) ile Bozkurt (2001)'den derlenmiş ve Şekil 1a'da verilmiştir. Şekil 1a'da görüldüğü gibi, Gümüşhane'nin Şiran, Kelkit ve Köse ilçeleri ile Bayburt ve Erzincan'dan geçen KAFZ ile ilişkili Kelkit Fay segmenti (KLFS), Kelkit baseni (KLB), Bayburt baseni (BYB), KelkitÇoruh Fay zonu (KÇFZ), Akdağ-Çayırlı Fay zonu (AÇFZ), Tercan-Aşkale Fay zonu (TAFZ) ve Dağyolu fayı (DYF) gibi birçok fay segmenti ve fay zonları mevcuttur. KÇFZ yaklaşık olarak $600 \mathrm{~km}$ uzunluktadır ve sol yönlü doğrultu atımlı fay zonudur. Bu fay zonu güney batıdan kuzey doğuya doğru Kelkit, Çoruh, Posof ve Borjomi-Kasbeg fay segmentleri olmak üzere dört segmentten oluşur. KLFS yaklaşık 100 km'lik bir uzunlukla KAFZ'den ayrılır. Kelkit civarında bu fay segmenti iki kola ayrilır ve bir basen ile sonuçlanır (Bozkurt, 2001). TAFZ yaklaşı $150 \mathrm{~km}$ uzunlukta olup 2-4 km genişliktedir ve sol yönlü doğrultu atımlı fay zonudur. Bu fay zonu KAFZ'ye yakın bir şekilde Erzurum'un batısından geçer ve yaklaşık 2-20 km uzunluğa sahip birbirine paralel çok sayıda fay segmentini içerir. (Bozkurt, 2001). Gümüşhane sınırına en yakın bölge için büyük sayılabilecek iki deprem 19 Ocak $1979\left(M_{\mathrm{D}}=5.0\right)$ ve 12 Ağustos $1985 \quad\left(M_{\mathrm{D}}=5.0\right)$ depremleridir. Gümüşhane ve civarında 1970-2016 yılları arasında meydana gelmiş depremlerin episantr dağılım haritası Şekil 1b'de verilmiştir. Şekil 1b'de görüldüğü gibi magnitüdü 5.0'dan büyük depremlerin büyük 
bir kısmı KAFZ ve civarında meydana gelirken (13 Mart $1992, M_{\mathrm{D}}=6.5$ ve 15 Mart 1992, $M_{\mathrm{D}}=5.3$ Erzincan) diğer depremler Gümüşhane'nin KAFZ'ye yakın alanlarda yoğunlaşmıştır. $\mathrm{Bu}$ depremlerden son yıllarda gözlenenler, 30 Temmuz $2009 \quad\left(M_{\mathrm{D}}=5.0\right)$ Erzincan-Çağlayan ve 22 Eylül 2011 $\left(M_{\mathrm{D}}=5.6\right)$ Erzincan-Refahiye depremleridir. Gümüşhane ve civarının jeolojik, tektonik ve sismik yapısının anlatıldığı çalışmalar Taş vd., (2003) ile Bozkurt (2001)'de detayl1 olarak mevcuttur.

\section{3. Çalışmada Kullanılan Deprem Kataloğu ve Ayrıştırma İşlemi}

Çalışmada kullanılan deprem verisinin 19702006 yılları arasındaki bölümü Öztürk (2009)'tan alınmıştır. 1970-2006 yılları arasında Türkiye ve civarını kapsayan ve 73,530 depremi içeren bu aletsel deprem kataloğu süre magnitüdüne $\left(M_{D}\right)$ göre homojendir. $\mathrm{Bu}$ veri seti, farklı magnitüd türlerini de içermekle birlikte genel olarak $M_{D}$ türünden verilmiştir. Öztürk (2009), 19702006 yılları arasında homojen ve sürekli bir deprem kataloğu hazırlayabilmek için bazı istatistiksel ilişkiler kullanmıştır (farklı magnitüd türleri için geliştirilen tüm bağıntılar ayrıca Bayrak vd., 2009'ta bulunabilir). 1970-2006 y1lları arasında $M_{D}$ 'si bilinmeyen az sayıdaki orta ve üzeri büyüklükteki depremlerin $M_{D}$ değerleri bu istatistiksel ilişkiler kullanılarak hesaplanmıştır. Bu veriye ek olarak 20062016 yılları arasındaki deprem verisi ise Boğaziçi Üniversitesi, Kandilli Rasathanesi ve Deprem Araştırma Enstitüsü (KRDAE) web sayfasında verilen deprem kataloğundan derlenmiştir. KRDAE, depremler için süre magnitüdünün hesaplanmadığı durumlarda genellikle yerel magnitüdü $\left(M_{L}\right)$ hesaplar. KRDAE deprem kataloğu incelendiğinde deprem verisinin 2010 yilına kadar olan kısmının genellikle $M_{D}$ türünden verildiği görülür. Ancak, 2011 yılı itibariye deprem kataloğunda bazı depremlerin yerel magnitüd $(M l)$ değerlerinin de verildiği görülmektedir. Dolayısıyla, 45.76 yıllık bir deprem verisinin yalnızca yaklaşık son 6 yıllık kısmının $M l$ ile verildiği dikkate alındığında, farklı magnitüd türleri arasındaki dönüşümlerden kaynak- lanan hataların mümkün olduğunca en aza indirgenmesi sonuçların doğruluğu açısından önemlidir. Dolayısıyla, 2006-2016 yılları arasında KRDAE kataloğunda Öztürk (2009) tarafindan verilen ilişkiler kullanılarak $M_{D}$ hesaplanmış ve bu zaman periyodu için Türkiye ve civarında 114,701 deprem elde edilmiştir. Sonuç olarak, 1970-2016 yılları arasında Türkiye için $M_{D}$ 'ye göre homojen olan ve 188,231 depremi içeren bir katalog hazırlanmıştır. $39.5^{\circ} \mathrm{K}-41.0^{\circ} \mathrm{K}$ enlemleri ile $38.5^{\circ} \mathrm{D}-40.5^{\circ} \mathrm{D}$ boylamları arasinda kalan bölge çalışma alanı olarak seçilmiştir. Tüm deprem kataloğu içerisinden Gümüşhane ve civarını içine alan bu bölgede, 1970-2016 yılları arasında yaklaşık 45.76 yıllık bir zaman periyodunda $1.1 \leq M_{\mathrm{D}} \leq 6.5$ olan 2500 depremi içeren bir katalog elde edilmiştir. $M_{\mathrm{D}} \geq 1.1$ olan tüm depremlerin (orijinal katalog) ve $M_{\mathrm{D}} \geq 5.0$ olan bölge için büyük sayılabilecek depremlerin episantr dağılımları Şekil 1b'de verilmiştir.

Sismik durgunluğa bağlı olarak deprem tehlikesini değerlendirme çalışmalarının güvenilir olarak yapılabilmesi için deprem kataloglarının ana şok öncesinde ve sonrasında oluşabilecek sarsıntılar veya ana şoklardan bağımsız olarak gelişen yığılımlar deprem kataloğundan çıkarılmalıdır. Öncü şok, artçı şok ve deprem yığılımı gibi olaylar genellikle deprem sayılarının zamana bağlı değişimlerini ve ilişkili istatistikleri etkilediği için, depremsellik oran değişimlerinin nicel bir değerlendirmesini yapabilmek ve öncü sismik durgunlukları güvenilir bir şekilde ortaya koyabilmek için, deprem kataloğu içerisindeki bağımlı olayların ayrıştırılması gerekir. Sismik durgunluk değişimlerini belirleyebilmek için, bölgesel bir deprem kataloğunun ana şok ve ikincil deprem oluşumlarına ayrılması yani bağımlı ve bağımsız olayların birbirinden ayrilması gerekir (Öztürk, 2009). Bu bağımlı olayları bağımsız depremlerden ayırabilmek ve deprem kataloğunu tekdüze hale getirebilmek için Reasenberg (1985) ayrıştırma algoritması kullanılır. $\mathrm{Bu}$ işlem bölgesel bir deprem kataloğunu ana olaylara ve ikincil olaylara ayrıştırır ve tüm bağımlı olayları her bir kümeden uzaklaştırır (Arabasz ve Hill, 1996). 

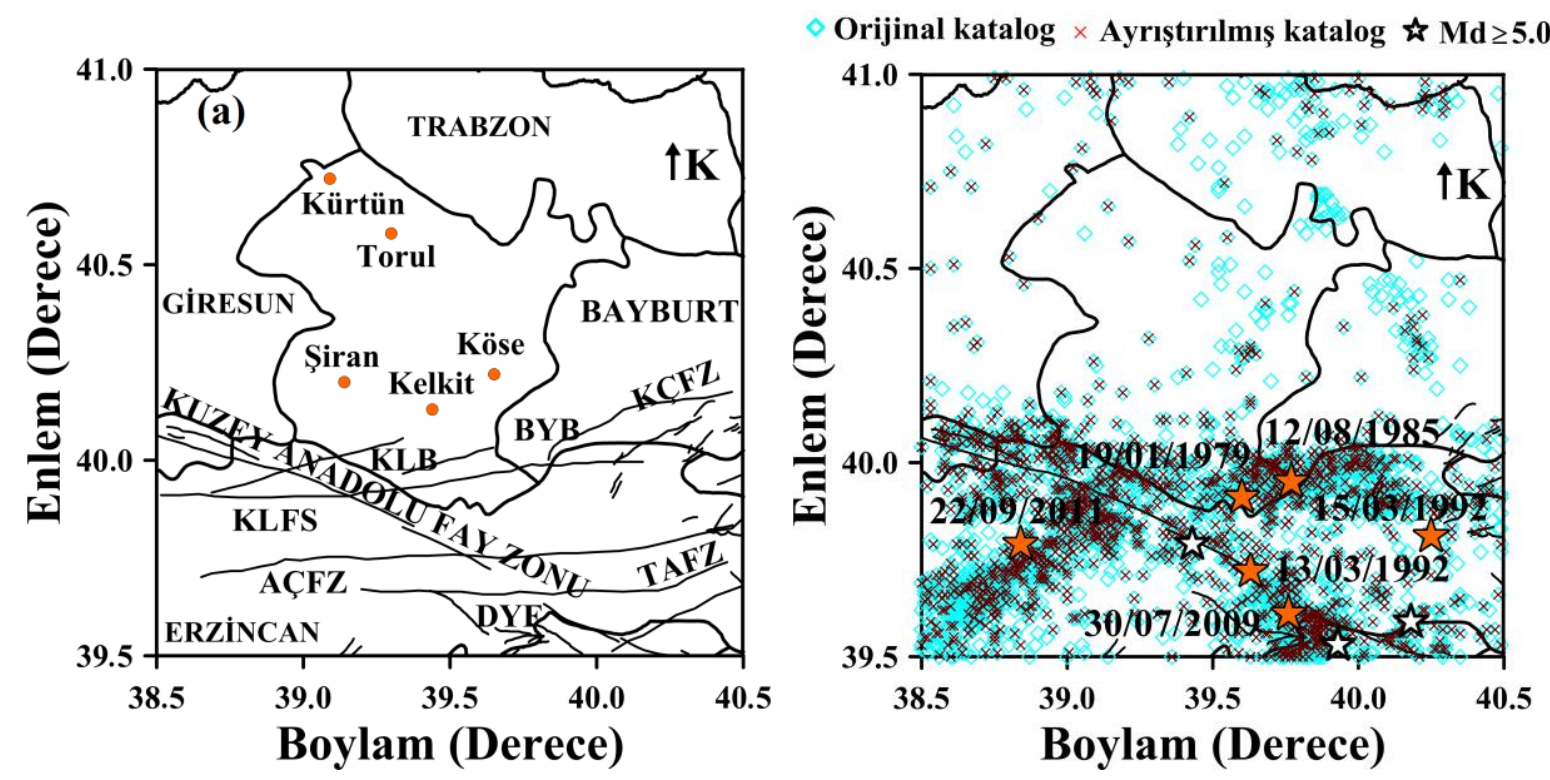

Şekil 1. (a) Gümüşhane ve civarı için ana tektonik yapı. Faylar, Şaroğlu vd., (1992) ve Bozkurt, (2001)'den değiştirilerek alınmıştır. (b) 1970-2016 yılları arasındaki $M_{\mathrm{D}} \geq 1.1$ olan tüm depremlerle birlikte (orijinal katalog) $M_{\mathrm{D}} \geq 2.8$ olan ayrıştırılmış depremler. Yıldız sembolü $M_{\mathrm{D}} \geq 5.0$ olan bölge için büyük sayılabilecek depremleri göstermektedir. Bazı büyük depremlerin ( $\star$ sembolü) meydana geliş tarihleri şekil üzerinde verilmiştir.

Aslında bu ayrıştırma işlemi, ana olayların episantrına kıyasla küçük veya büyük bölge ve zaman aralığındaki ikincil olayların uzaklaştırılmasını sağlayan bir aşamadır. Depremlerin sismik durgunluk analizlerinin tam bir deprem kataloğu yani öncü şok, artçı şok, deprem yığılımları ve deprem çiftleri gibi ikincil olayları içeren bir deprem kataloğu kullanılarak yapılması güvenilir ve doğru sonuçlar ortaya koymayabilir ve dolayısıyla tüm kümelenmiş olayların ayrılması gerekir. Aksi takdirde büyük ana şokların tahmini için yanlış tahminler yapılabilir çünkü magnitüd-frekans eğrisinin eğimi ana şok olmayan olaylardan etkilenir. Dolayısıyla, bağımlı olayların uzaklaştırılması, magnitüd-frekans eğrisini daha az eğimli yapacak ve deprem oluşumlarının tahmininde daha güvenilir sonuçlar verecektir (Öztürk, 2009). Birçok araştırmacı dünyanın farklı bölgeleri için, ayrıştırma işleminin farklı deprem kataloglarına uygulanabileceğini göstermiş ve önemli sonuçlar elde etmişlerdir (örneğin, Arabasz ve Hill, 1996, Katsumata ve Kasahara, 1999, Console vd., 2000, Chouliaras ve Stavrakakis, 2001, Wu ve Chiao., 2006, Öztürk, 2011, 2015b).
$\mathrm{Bu}$ çalışmada öncü sismik durgunluk analizinde kullanılan deprem kataloğu, Reasenberg (1985) ayrıştırma yöntemi ile elde edilmiştir. Orijinal deprem kataloğu $M_{\mathrm{D}} \geq 1.1$ olan 2500 depreme sahiptir. Ayrıştırma işlemi kullanılarak 438 deprem katalogdan çıkarılmış ve 2062 deprem ayrıştırılmıştır. Gümüşhane ve civarı için tamlık magnitüdü $M c=2.8$ olarak hesaplanmış ve $M_{\mathrm{D}}<2.8$ olan depremler katalogdan çıkarılmıştır. $\mathrm{Bu}$ işlem sonucunda 726 deprem daha katalogdan uzaklaştırılmıştır. Böylece toplamda yaklaşık olarak depremlerin \% 46.56'sı katalogdan çıkarılmış ve sismik durgunluk analizi için kullanılan deprem sayısı 1336 olarak elde edilmiştir. Sonuç olarak, ayrıştırma işlemi çalışmanın amacına yönelik olarak daha kullanılabilir ve tek düze bir deprem kataloğu ortaya koyar. $M_{\mathrm{D}} \geq 2.8$ olan ayrıştırılmış depremlerin episantr dağılım haritası orijinal katalogla birlikte Şekil 1b'de verilmiştir.

\section{Sismotektonik $b$-değeri ve Standart Normal Sapma Z-Testi}

Deprem aktivitesinin bölgesel ve zamana bağlı davranışlarını karakterize edebilmek 
için bazı istatistiksel boyut ölçeklendirme parametreleri kullanılır. Bu bölümde, deprem oluşumları için Gutenberg-Richter ilişkisi ile verilen sismotektonik $b$-değeri ve depremsellik oran değişimlerini veren standart normal sapma Z-değerinin hesaplanması ile ilgili yöntemlerden kısaca bahsedilecektir.

\subsection{Gutenberg-Richter İlişkisi (b-değeri) ve Tamlık Magnitüdü (Mc)}

Depremlerin sayısı ile magnitüdü arasındaki ilişki ilk kez Gutenberg-Richter (1944) tarafından verilmiştir. Depremlerin bu güç yasası dağılımı aşağıdaki denklemle ifade edilir:

$$
\log _{10} N(M)=a-b M
$$

Burada $N(M)$, verilen bir zaman periyodunda magnitüdü $M$ 'den büyük veya eşit olan depremlerin beklenen sayısı, $b$-değeri deprem sayısı-magnitüd dağılımının eğimi ve $a$ değeri ise deprem aktivite oranı ile ilişkili bir parametredir. $a$-değeri bölgeden bölgeye değişir ve bu değişim çalışma alanının büyüklügün, gözlem periyoduna ve ayrıca depremlerin büyüklüğüne bağlıdır. Utsu (1971), b-değerinin farklı bölgelere bağlı olarak genellikle 0.3-2.0 arasında değiştiğini ifade etmiştir. $b$-değerindeki değişimler ayrıca bir bölgedeki büyük ve küçük depremlerin sayısı, jeolojik karmaşılık, gerilme, yamulma ve kırıklı ortamın heterojenite derecesi gibi faktörlere de bağlıdır. Yüksek $b$-değerlerinin gözlenmesi genel olarak bölgede büyük olaylara nazaran küçük olayların sayısında bir artış olduğunu, buna karşın düşük $b$-değerleri ise büyük olayların sayısında bir artma olduğunu gösterir. Frohlich ve Davis (1993)'te ifade edildiği gibi, bölgesel olarak ortalama $b$ değerinin 1.0'a eşit olduğu kabul edilir.

Tamlık magnitüdü $M c$, özellikle GutenbergRichter ilişkisinin tahmini başta olmak üzere birçok istatistiksel depremsellik çalışmalarında en önemli parametrelerden biridir. Yüksek kalitede ve güvenilir tahminler için maksimum deprem sayısının kullanılması çok önemlidir. Magnitüde karşı
Gutenberg-Richter güç yasası dağılımı $M c$ değerini tahmin etmek için kullanılabilir ve $M c$-değerindeki değişimler hareketli bir zaman penceresi tekniği ile hesaplanabilir (Wiemer ve Wyss, 2000). Mc-değerindeki zamana bağlı değişimler özellikle $b$-değeri olmak üzere depremsellik parametreleri üzerinde önemli bir etkiye sahiptir. Eğer $M c$ değeri zamanın bir fonksiyonu olarak sistematik bir şekilde değişim gösteriyorsa yanlış $M c$-değeri hatalı depremsellik parametrelerinin hesabına neden olabilir. Dolayısıyla, $M c$ analizi önemli bir işlemdir ve istatistiksel analizler için en uygun $M c$ değerinin seçilmiş olması gerekir.

\subsection{Standart Normal Sapma Z-Testi}

Deprem aktivite oranındaki değişimleri analiz eden modeller genellikle sismik durgunluk olgusu üzerinde odaklanır. Standart normal sapma Z-testi, deprem aktivitesindeki oran değişimlerinin ölçümü için en sık kullanılan ve en iyi bilinen istatistiksel yöntemlerden biridir. Bu test Wiemer ve Wyss (1994) tarafından verilen yöntem ve Wiemer (2001) tarafindan verilen ZMAP yazılımı ile yapılabilir. Bu teknik, bölgesel ve zamana bağlı deprem aktivite oran değişimlerini sürekli bir görüntü olarak haritalamaya ve yorum yapabilmeye olanak sağlar. Durgunluğun önemini ortaya koyabilmek için LTA (Log Term Average) fonksiyonunu oluşturan standart normal sapma Z-testi kullanılır:

$$
Z=\left(R_{1}-R_{2}\right) /\left(S_{1}^{2} / N_{1}+S_{2}^{2} / N_{2}\right)^{1 / 2}
$$

Burada $R_{1}$; verilen bir $t_{0}-t_{\mathrm{e}}$ aralığındaki zaman penceresini $\left(T_{W}\right)$ içeren tüm zamanlardaki ortalama depremsellik oranı (deprem sayıs1), $R_{2}$; $t$ 'den $t+T_{W}$ 'ye kadar olan düşünülen zaman penceresindeki ortalama oran, $S_{1}^{2} v e$ $S_{2}^{2}$ ise bu periyotlardaki sismik yoğunluk fonksiyonlarının standart sapmaları ifade eder. $N_{1}$ ve $N_{2}$ ise ölçülen depremsellik oranındaki örneklerin sayısı ile ilişkilidir. $t_{0}$ ile $t_{e}-T_{W}$ arasındaki tüm $t$ zamanları için (2) denklemi ile hesaplanan Z-değeri (Şekil 3), bir $T_{W}$ (bazen $\mathrm{i} w l$ ) zaman penceresindeki (ayrica i $w l$ olarak ta verilir) depremsellik oran 
değişimlerinin ölçümü için istatistiksel bir değerlendirme ortaya koyar. Zamanın bir fonksiyonu olarak Z-değeri LTA olarak adlandırılır. Durgunluğun süresi hesaplanacak önemli bir parametredir. Durgunluğun ne zaman sona ereceği bilinmediği için zaman penceresi 1.5-5.5 y1l arasında değiştirilir. Çünkü bu değer dünyanın farklı bölgeleri için, kabuksal ana şoklardan önce rapor edilen sismik durgunluk oranı ile uyumludur (Wyss, 1997).

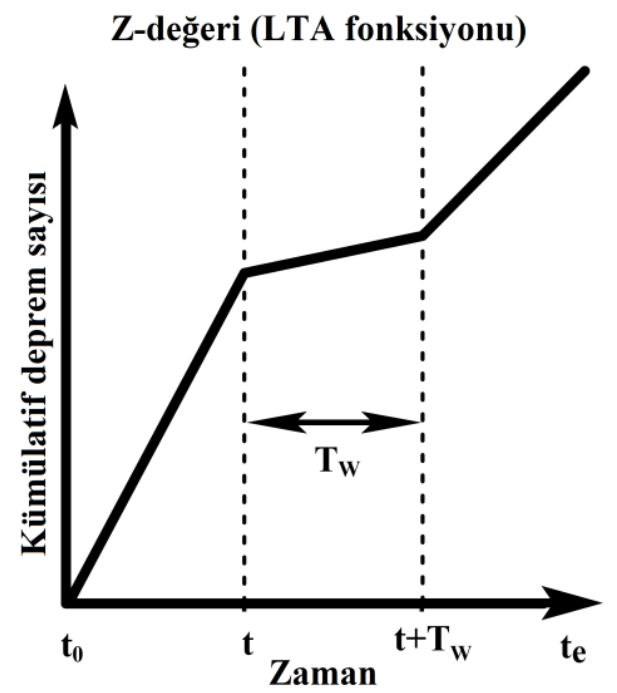

Şekil 2. Z-değerlerinin nasıl hesaplandığını gösteren grafik. $R_{1}$; tüm periyottaki ortalama oran ( $t_{0}-t_{\mathrm{e}}$ aralığında), $R_{2}$; $t^{\prime}$ 'den $t+T_{W}$ 'ye kadar olan zaman penceresindeki ortalama oran1 ifade eder. Burada $t$; mevcut zamandir $\left(t_{0}<t<t_{\mathrm{e}}\right)$ ve $T_{W}$; y1l olarak zaman penceresinin uzunluğudur.

\section{Bulgular ve Tartışma}

$\mathrm{Bu}$ çalışma kapsamında Gümüşhane ve civarındaki deprem aktivitesinin bölgesel ve zamana bağlı değişimleri istatistiksel olarak analiz edilmiştir. Orijinal deprem kataloğu ve ayrıştırılmış katalog için kümülatif deprem sayısının zamanla değişimi Şekil 3'te verilmiştir. Şekil 3'te görüldüğü gibi 19701995 yılları arasında önemli bir deprem aktivitesi yoktur fakat 1995 'ten 2003'e kadar olan sürede deprem sayısında bir artış söz konusudur. Bununla birlikte 2003 y1lından itibaren deprem sayısında önemli bir artış gözlenmektedir. Ayrıca Şekil 4a'da verilen zaman histogramından görüleceği gibi, 2003 yılında deprem sayılarında önemli bir artış kaydedilirken deprem sayısındaki maksimum artış 2011 yılında gözlenmiştir. Bununla birlikte, 2011 y1lından itibaren kaydedilen deprem sayıları tekrar bir azalım sürecine girmiştir. KRDAE özellikle 2000'li yıllardan sonra istasyon sayısındaki artışla birlikte internet üzerinden ve uzaktan kontrollü modem vasıtasıyla gerçek zamanlı verileri kullanıcının hizmetine sunmaktadır. İstasyon ağındaki bu artış, daha önceki yıllarda kayıt altına alınamayan birçok depremin 2000'li yıllardan sonra düzenli olarak kayıt edilmesine olanak sağlamıştır. Ayrıca, çalışma alanı içerisinde büyük sayılabilecek depremlerin en sonuncusu 2011 yilında meydana gelmiştir. Dolayısıyla, 2003-2011 yılları arasında deprem sayısında gözlenen bu artış, çalışma alanına yakın olan Erzincan'da meydana gelmiş orta büyüklükte veya büyük depremlerin artçı şoklarının veya devam eden süreçteki diğer deprem aktivitelerinin çalışma alanına düşmüş olmasından kaynaklanabilir. Şekil 4b'de görüldüğü gibi katalogdaki deprem magnitüdleri 1.1 ile 6.5 arasında değişim gösterir ve üstel olarak azalır. Depremlerin büyük bir kısmı 2.5-3.5 magnitüd seviyesinde değişim gösterirken $M_{\mathrm{D}}=2.8$ değerinde bir maksimum söz konusudur. Deprem sayılarında son yıllarda gözlenen artışın sebebi, Şekil 1b'de görüldüğü gibi KAFZ ve civarında 2003 yılından itibaren bölge için büyük sayılabilecek depremlerin sayısındaki artış olarak verilebilir. Ayrıca, bu bölgelerde son yıllarda kurulmuş olan istasyonların sayısında olan artışla birlikte gerçek zamanlı verilerin kayıt edilmesi de bu artış üzerinde etkilidir. Şekil 3'te görüldüğü gibi zamanın bir fonksiyonu olarak $M_{\mathrm{D}} \geq 2.8$ olan ayrıştırılmış depremlerin kümülatif sayıları orijinal kataloğa kıyasla daha düz bir eğime sahiptir. Dolayısıyla, Reasenberg (1985) algoritmas1 kullanılarak yapılan ayrıştırma işılemi bağımlı olayları katalogdan çıkarmış ve sonuçta depremsellik oran değişimleri için daha homojen, güvenilir ve tekdüze bir deprem kataloğu elde edilmiştir. Sismik durgunluk ve magnitüd-deprem sayısı ilişkisini araştırabilmek için, hareketli pencere tekniği ile $M c$-değerinin zamanla değişimi analiz edilmiştir. 
Şekil 3. $M_{\mathrm{D}} \geq 1.1$ olan 2500 depremi içeren orijinal katalog ve $M_{\mathrm{D}} \geq 2.8$ olan 1336 depremi içeren ayrıştırılmış katalog için kümülatif deprem sayısının zamanla değişimi.
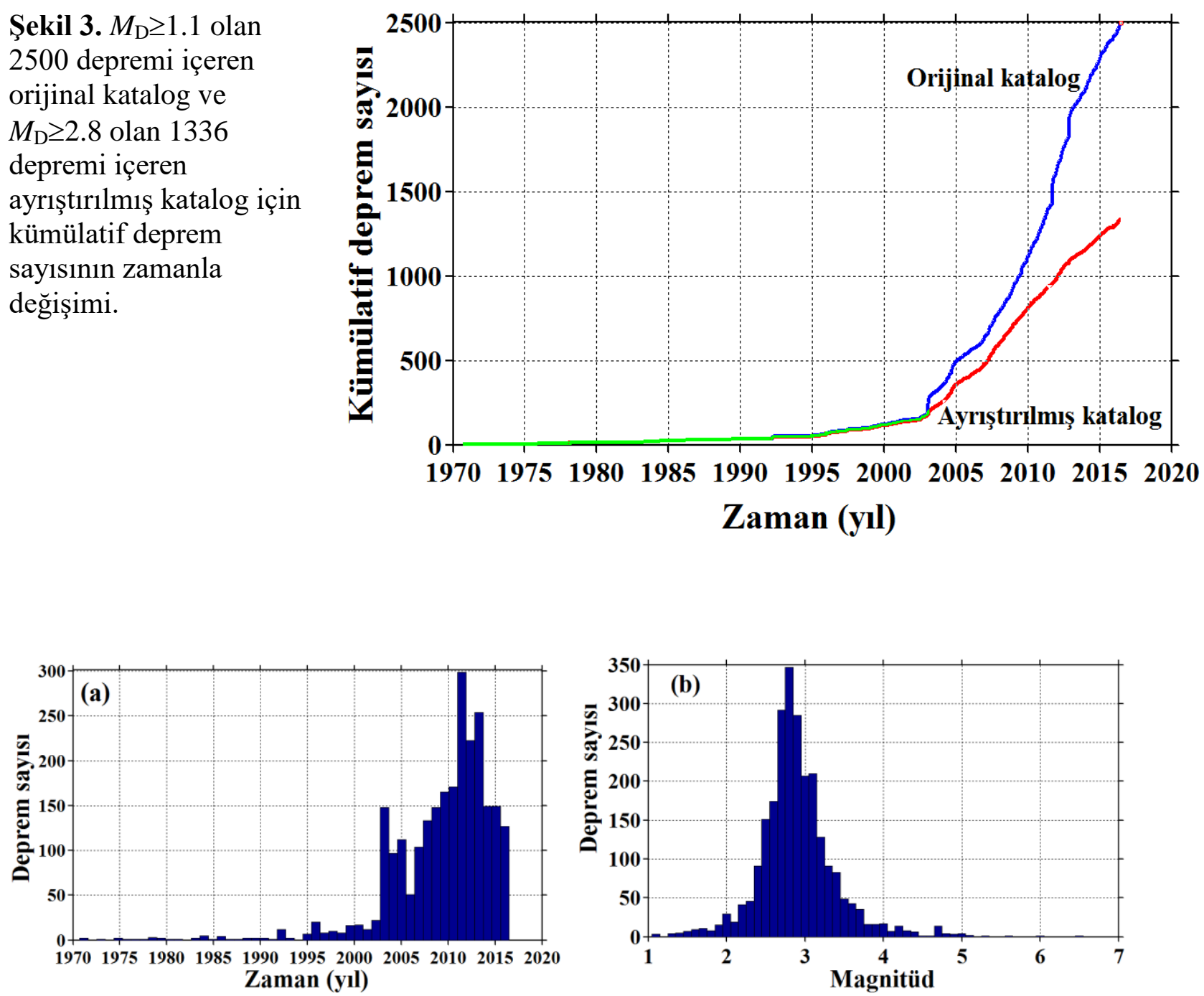

Şekil 4. Gümüşhane ve civarı için 1970-2016 yılları arasındaki (a) zaman histogramı $(b)$ magnitüd histogram1.

Şekil 5, Gümüşhane ve civarı için $M c$ değerinin zamanla değişimini göstermektedir. $M c$-değerinin analizinde $M_{\mathrm{D}} \geq 1.1$ olan ve 2500 depremi içeren orijinal deprem kataloğu kullanılmış ve $M c$-değeri pencere başına 100 örnek kullanılarak hesaplanmıştır. $M c$-değeri 2000 y1lına kadar oldukça yüksektir ve 3.54.5 arasında değişim gösterirken 2000-2005 y1lları arasında $M c=3.0$ seviyesine kadar azalım gösterir. Daha sonra 2005 yılından itibaren 3.0'dan daha düşük değerler sergiler ve 2005-206 yılları arasinda 2.5 ile 3.0 seviyelerinde değişim gösterir. $M c$-değeri zamanla sabit bir değer değildir ve birçok depremsellik çalışmasında büyük bir öneme sahiptir. Sonuç olarak Gümüşhane ve civarı için $M c$-değeri 2.5-3.0 arasında değişim gösterir ve istatistiksel analizlerde ortalama olarak $M c=2.8$ kabul edilmiştir.

Gutenberg-Richter ilişkisindeki $b$-değeri ve standart sapması maksimum olasılık yöntemi kullanılarak hesaplanmıştır çünkü en küçük kareler yöntemine kıyasla daha doğru bir yaklaşım sunar (Aki, 1965). Şekil 6, Gümüşhane ve civarı için Gutenberg-Richter ilişkisini ve $b$-değerini göstermektedir. Orijinal deprem kataloğu kullanılarak $M c$ değeri 2.8 olarak alınmış ve $b=1.01 \pm 0.02$ olarak hesaplanmıştır. Tektonik depremler genellikle $b \approx 0.5-1.5$ arasındaki değerlerle karakterize edilir. 
Şekil 5. Gümüşhane ve civarı için 1970-2016 arasında $M c$ değerinin zamanla değişimi. Şekil üzerinde standart sapma $(\delta M c)$ değeri de verilmiştir. $M c$-değeri pencere başına 100 deprem kullanılarak grafiklenmiştir.

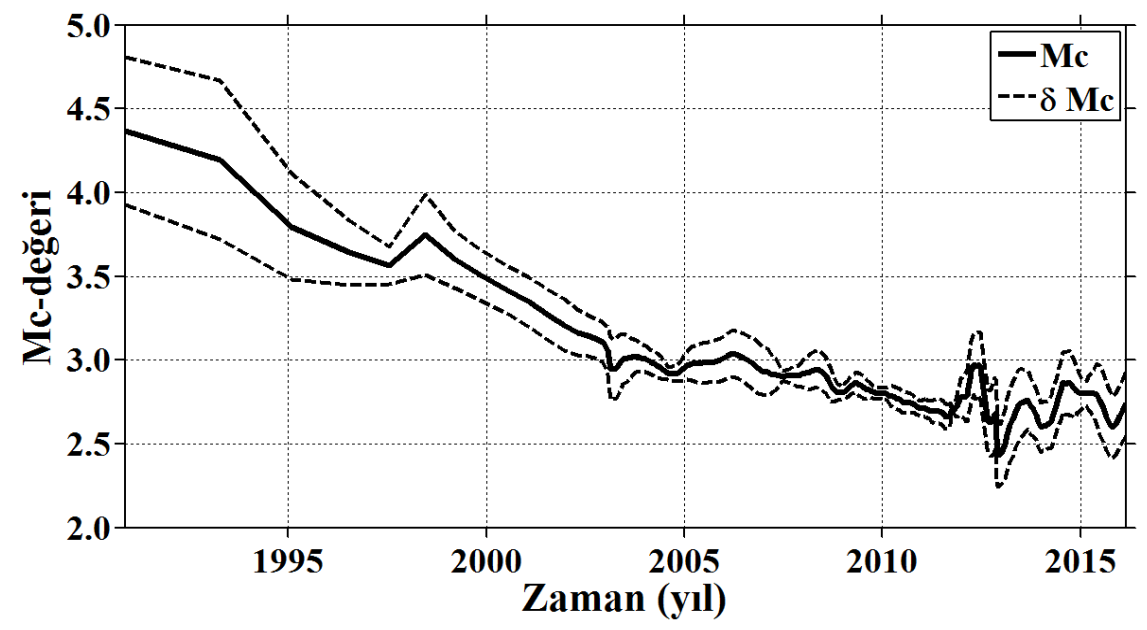

Hesaplanan değerden de görüleceği gibi, Gümüşhane ve civarı için $b$-değeri tektonik depremlerin genel karakteristiği ile uyumludur yani depremlerin magnitüd- frekans dağılımı tipik olarak ortalama $b=1.0$ ile verilen Gutenberg-Richter ilişkisi ile çok iyi temsil edilir.

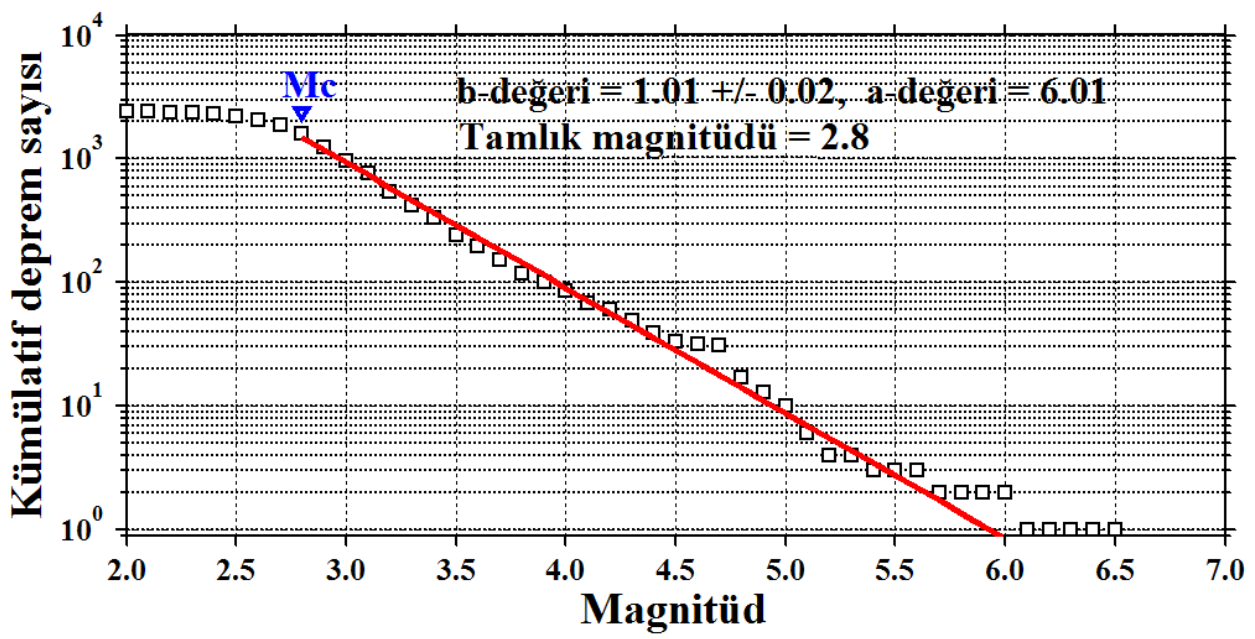

Şekil 6. Gümüşhane ve civarı için 1970-2016 arasındaki tüm depremler için Gutenberg-Richter ilişkisi ve magnitüd-frekans dağılımı. Gutenberg-Richter ilişkisindeki $a$-değeri ile birlikte tamlık magnitüdü, $b$-değeri ve standart sapması da şekil üzerinde verilmiştir.

Gümüşhane ve civarı için $b$-değerinin zamanla değişimi Şekil 7'de verilmiştir. $b$ değerinin zamanla değişimi pencere başına 300 depremlik bir örnekleme ile hesaplanmıştır. 2003 yılı başlarına kadar $b$ değerinde sistematik bir artış söz konusudur ve $b \sim 1.5$ değerine kadar yükselmiștir. Bununla birlikte bölge için büyük sayılabilecek hiçbir deprem olmamasına rağmen 2003-2004 yılları arasında $b$ değerinde bir düşüş gözlenmiş ve $b \sim 1.3$ civarına kadar azalmıştır. 2004-2009 yılları arasında $b \sim 1.5$ değerinde durağan bir dağılım gösteren $b$-değeri 2010 yılının sonlarına kadar sistematik bir artış göstermiş ve $b \sim 1.8$ civarına kadar yükselmiştir. 2011 yılından itibaren keskin bir düşüş gösteren $b$-değeri, 2013 y1lına kadar azalmaya devam etmiştir. Öztürk (2011), ana şoklardan önce $b$ değerinde gözlenen düşüşe gerilmedeki bir atışın neden olabileceğini ve bu tür anomalilerin gelecek depremlerin tahmininde 
kullanılabileceğini ifade etmiştir. Şekil 7'de görüldüğü gibi, 22 Eylül 2011 ve 31 Ağustos 2012 depremlerinden önce $b$-değerlerinde güçlü azalımlar söz konusudur. Bununla birlikte $b$-değeri genel olarak 1.0'dan büyüktür ve 2013 yılından itibaren bir artış eğiliminde olan $b$-değeri 2014 yilından itibaren $b \approx 1.3$ değerinde durağan bir dağılım göstermektedir.

Gümüşhane ve civarı için $b$-değerinin bölgesel değişimi, orijinal deprem kataloğu kullanılarak $0.02^{\circ} \times 0.02^{\circ}$ 'lik bir grid aralığ ile pencere başına 400 deprem alınarak maksimum olasılık yöntemiyle haritalanmış ve Şekil 8'de verilmiştir. $b$-değeri bölgesel olarak 0.7-1.5 arasında değişim göstermektedir. En yüksek $b$-değerleri $(>1.2)$ Kürtün, Torul ve Şiran'1 içine alan batı ve kuzey batı kısımlar ile Şiran'ın güneyinde hesaplanmıştır. En düşük $b$-değerleri ise $(<0.9)$ Kelkit ve Köse'yi içine alan doğu ve kuzey doğu kısımlar ile Köse'nin kuzeyinde ve Kelkit'in güneyinde gözlenmiştir. Bir bölge için $b$-değeri yalnızca büyük ve küçük depremlerin sayısını yansitmaz aynı zamanda bölgedeki gerilme koşullarıyla da ilişkilidir (Utsu, 1971). Genel olarak, GutenbergRichter yöntemi kullanılarak maksimum olasılık yöntemiyle tahmin edilen $b$-değerleri tektonik ve depremselliğe iyi bir uyum sağlamaktadır ve düşük $b$-değerlerinin gözlendiği bölgelere dikkat edilmelidir.

Şekil 9, Gümüşhane ve civarındaki depremler için farklı magnitüd seviyelerindeki yıllık olasılıkları ve tekrarlama zamanlarını göstermektedir. Şekil 9a'da görüldüğü gibi, farklı magnitüd seviyelerindeki deprem oluşumlarının yıllık olasılıkları 3.5-4.0 magnitüd seviyeleri arasında nispeten 1'den daha yüksek değerler gösterirken 4.0'dan daha küçük magnitüd seviyeleri için 1 'den daha küçük yıllık olasılıklar göstermektedir. Şekil 9b, farklı magnitüd seviyeleri için deprem oluşumlarının tekrarlama zamanlarını göstermektedir. Şekil 9b'den görüldüğü gibi depremlerin tekrarlama zamanları, 3.5-5.0 magnitüd seviyeleri arasında 10 yıldan daha az iken 5.0-6.0 magnitüd seviyeleri için 10100 yıl arasında ve 6.0'dan daha büyük magnitüd seviyeleri içinse 100 yıldan daha fazladır. Genel bir sonuç olarak, belirli magnitüd seviyeleri için deprem oluşumlarının tekrarlama zamanları ve olasılıkları üzerine yapılan bu analizler, Gümüşhane ve civarının bölge için büyük sayılabilecek deprem oluşumları açısından kısa vadede önemli bir deprem tehlikesi potansiyeline sahip olmadığını göster-mektedir.

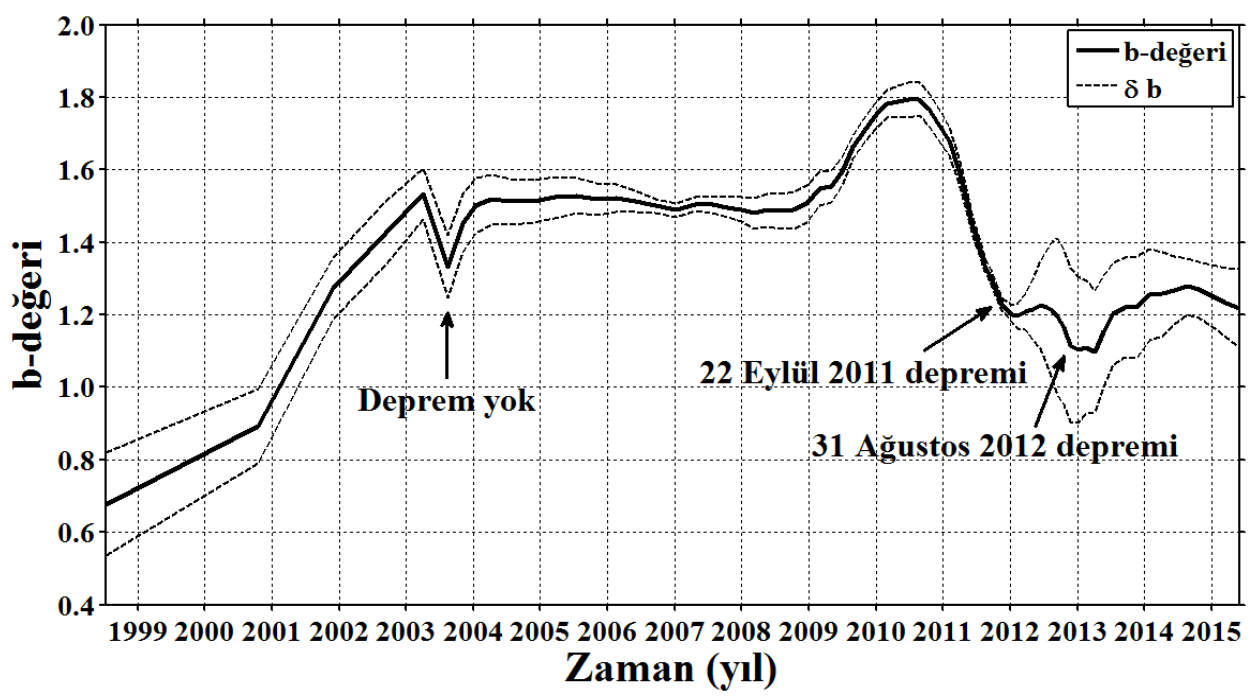

Şekil 7. Gümüşhane ve civarı için $b$-değerinin zamanla değişimi. $b$-değeri pencere başına 300 örnek kullanılarak hesaplanmıştır. $b$-değerinin standart sapması da $(\delta b)$ şekil üzerinde verilmiştir. Oklar, Gümüşhane ve civarındaki güçlü depremlerin oluşumundan önce $b$-değerindeki düşüşleri göstermektedir. 


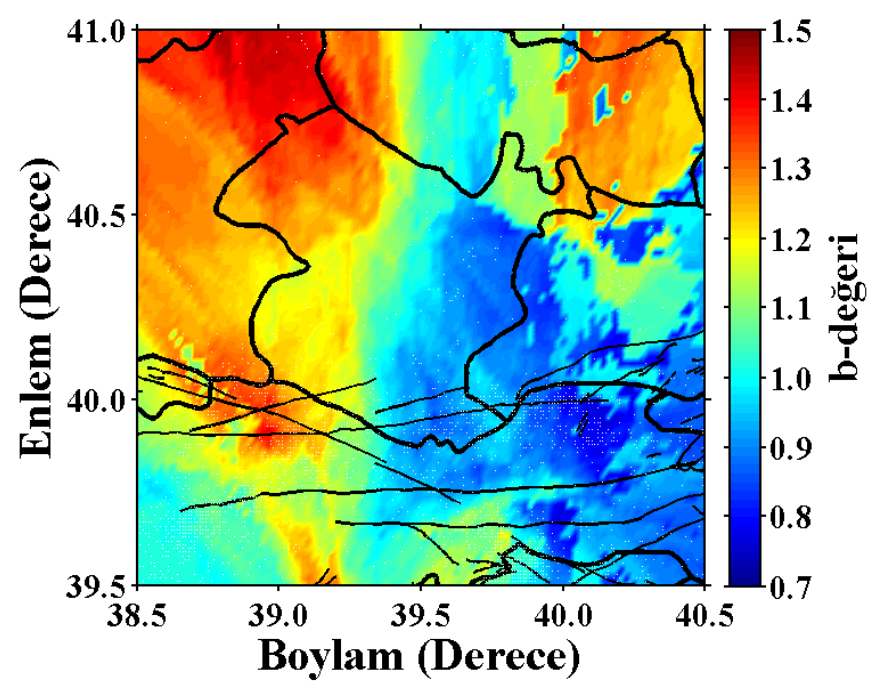

Şekil 8. Gümüşhane ve civarı için sismotektonik $b$-değerinin bölgesel değişim haritası.

Gümüşhane ve civarı için 2016 y1lı ortalarında standart normal sapma Zdeğerinin bölgesel değişimleri Şekil 10 'da gösterilmiştir. Her bir Z-değeri farklı renklerle tanımlanmıştır. En düşük $Z$-değeri mavi renkle gösterilmiştir ve depremsellik oran değişimlerinin önemli olmadığını gösterir. Buna karşın en yüksek Z-değeri kırmızı renkte verilmiştir ve depremsellik oranında bir azalımı gösterir. Daha öncede ifade edildiği gibi, Z-değerinin bölgesel değişim haritasını oluşturabilmek için $M_{\mathrm{D}} \geq 2.8$ olan ve Reasenberg (1985) ile ayrıştırılmış deprem kataloğu kullanılmıştır. Çalışma alanı enlem ve boylamda $0.02^{\circ} \times 0.02^{\circ}$ 'lik grid aralıklarına bölünmüş ve birkaç testten sonra her bir grid aralığı için en yakın episantrların sayısı $N=75$ ve örnekleme aralığ1 28 gün alınarak $T_{W}=4.5$ yıllık bir hareketli zaman penceresi ile 2016 y1l ortalarında sismik durgunluk $Z$-değerinin güncel değişimi haritalanmıştır. Öncü sismik durgunluğun süresi hesaplanması gereken önemli bir parametredir ve güvenilir sonuçlar için hesapların seçilen $T w$ değerinden bağımsız olması istenir.
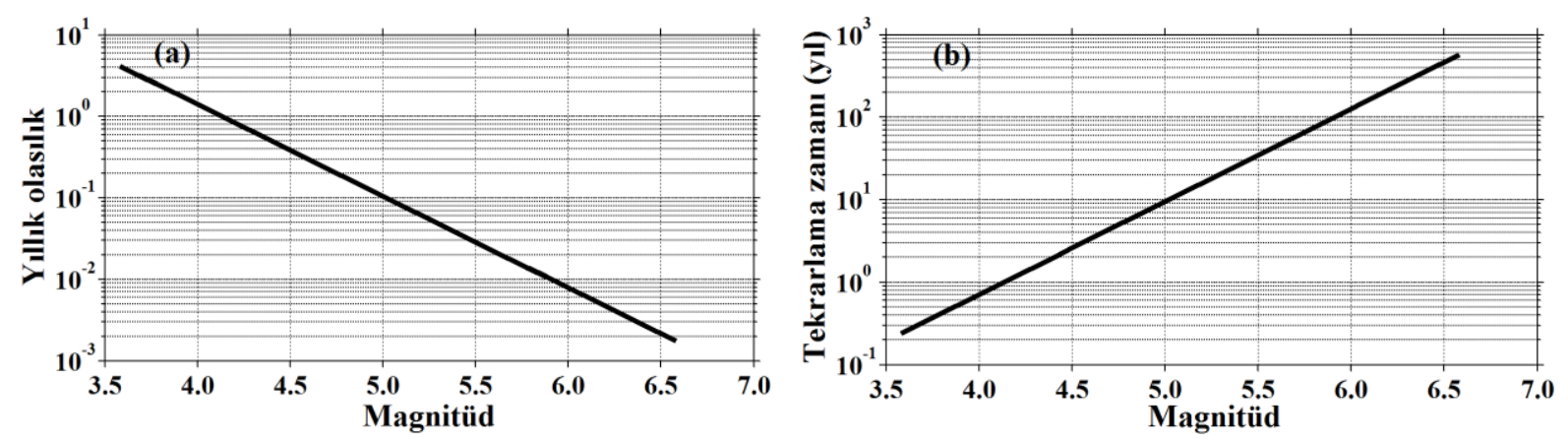

Şekil 9. Gümüşhane ve civarındaki deprem oluşumları için farklı magnitüd seviyelerindeki (a) yıllık olasılıklar $(b)$ tekrarlama zamanları.

Arabasz ve Wyss (1996), büyük depremlerden önceki sismik durgunluk süresinin ortalama $4.5 \pm 3$ yıl olduğunu ifade etmişlerdir. Dolayısıyla, sismik durgunluğun ne zaman sona ereceği bilinmediği için zaman penceresi 1.5-5.5 y1l arasında değiştirilir. Çünkü bu değer dünyanın farklı bölgeleri için, kabuksal ana şoklardan önce rapor edilen sismik durgunluk oranı ile uyumludur (Wyss, 1997). Sismik durgunluğun görüntüsü zaman penceresinin uzunluğuna bağlıdır ve pencerenin uzunluğu artarsa LTA fonksiyonunun istatistiksel güvenirliliği de artar (Wiemer ve Wyss, 
1994). Çalışma kapsamında Tw'nin farklı değerleri için yapılan analizlerden sonra zaman penceresi $T_{W}=4.5$ yıl olarak alınmıştır çünkü depremsellik oran değişimlerinin en net görüntüsü bu zaman penceresi için elde edilmiştir. Sonuç olarak $N$ ve $T_{W}$, sismik durgunluk sinyalini daha net görüntüleyebilmek için değiştirilir ve bu seçim sonuçları etkilemez. Şekil 10, Gümüşhane ve civarı için $Z$-değerinin bölgesel dağılımını göstermektedir. Şekil 10'da görüleceği gibi Gümüşhane sınırları içerisinde 2016 y1lı ortalarında herhangi bir önemli sismik durgunluk anomalisi gözlenmemiştir. Dolayısıyla, güncel deprem aktivite oranında herhangi bir dalgalanma yoktur ve bu sonuç, Gümüşhane sınırları içerisinde öncü sismik durgunluk açısından önemli bir deprem tehlikesi potansiyelinin olmadığını gösterir.

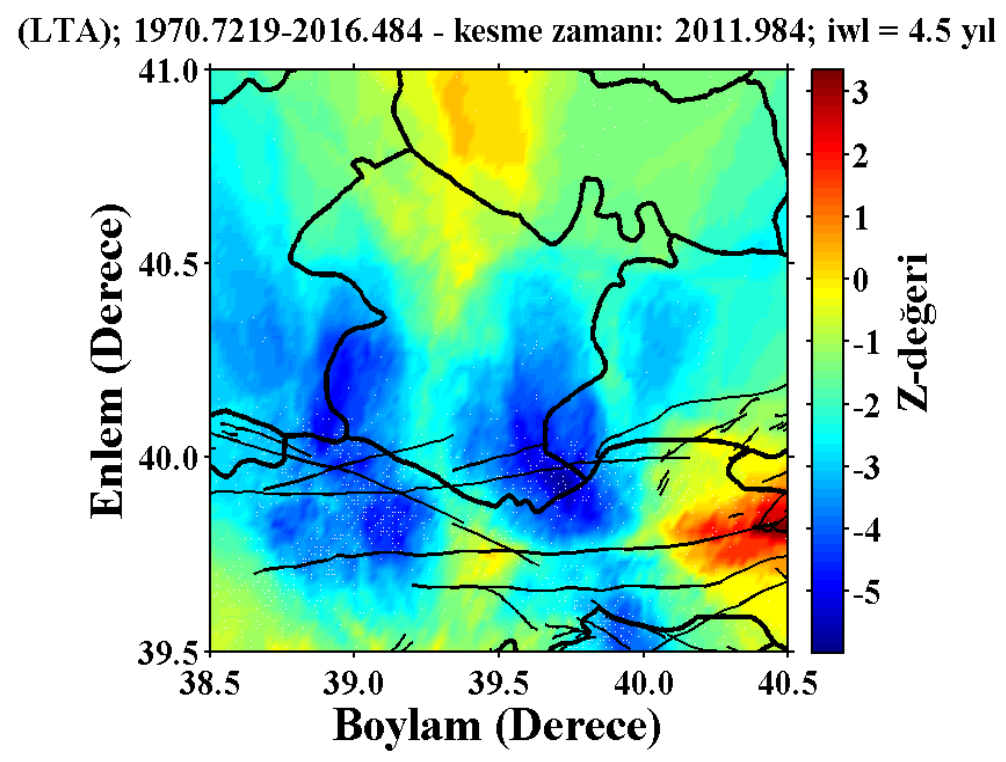

Şekil 10. Gümüşhane ve civarı için $T_{W}(\mathrm{i} w l)=4.5$ yıllık zaman penceresi ile 2016 yılı ortalarında Zdeğerinin bölgesel değişimi. Z-değerinin haritalanmasında $M_{\mathrm{D}} \geq 2.8$ olan ve 1336 depremi içeren ayrıştırılmış deprem kataloğu kullanılmıştır.

Gümüşhane ve civarı için deprem kataloğundaki önemli oran değișimlerinin tümünü görebilmek için GENAS (Habermann, 1983) algoritması kullanılmıştır. GENAS, farklı magnitüd değerleri için kümülatif sayıları hesaplar ve gözlenen değişimleri ayrı ayrı ortaya koyar. Magnitüd aralıklarının ayrı ayrı araștırılmasının amacı, belirgin değișimlerin olduğu magnitüd bandlarını birbirinden ayırmaktır. Şekil 11, farklı magnitüd aralıkları için önemli değişimleri ortaya koyan GENAS sonuçlarını göstermektedir. $\mathrm{Bu}$ algoritma, verinin sonundan başlayarak farklı magnitüd bandları için sismik aktivitedeki önemli değişimleri araştırır ve zamanın bir fonksiyonu olarak ortaya koyar. Şekil 11'de verilen tüm magnitüd bandları için "magnitüd ve altı", $M_{\mathrm{D}}$ 'den daha küçük bir magnitüde sahip tüm depremleri, "magnitüd ve üzeri" ise $M_{\mathrm{D}}$ 'den daha büyük bir magnitüde sahip tüm depremleri ifade eder. Şekil 11'de görüldüğg̈ gibi, 2002, 2003, 2004 ve 2016 y1llarında küçük depremlerin sayısında önemli artışlar gözlenirken, 2005 ve 2013 yıllarında küçük depremlerin sayısında güçlü azalmalar söz konusudur. Ayrica, 1995, 1996 ve 2007 yıllarında küçük depremlerin sayısında küçük artışlar mevcuttur. Bununla birlikte, 1976, 1992, 2002 ve 2003 yıllarında büyük depremlerin sayısında bir artma gözlenirken 1993, 2001 ve 2013 yllarında büyük depremlerin sayısında bir azalma söz konusudur. Sonuç olarak, GENAS sonuçları ile sismik durgunluk değişimleri, depremsellik oran değişimlerinin detaylı olarak analiz edilmesine olanak sağlar. 

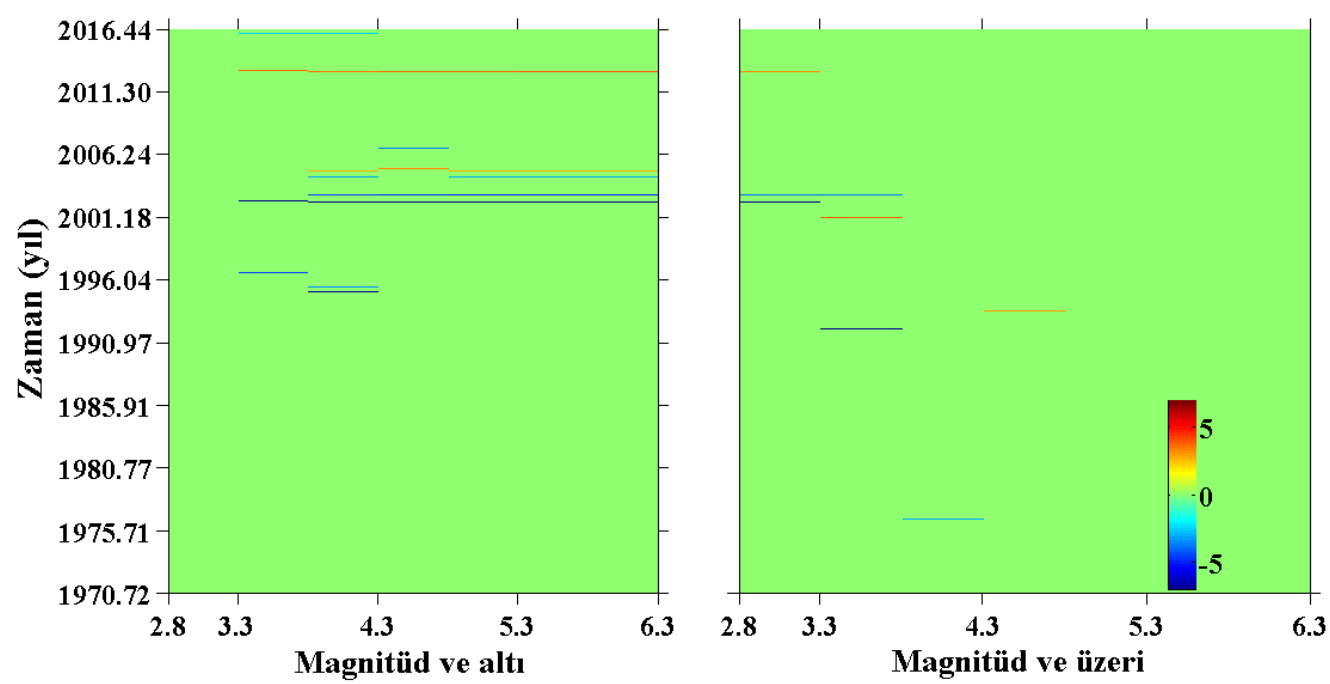

Şekil 11. $M_{\mathrm{D}} \geq 2.8$ olan ayrıştırılmış deprem kataloğu için GENAS sonuçları. Zamanın bir fonksiyonu olarak önemli depremsellik oran değișimleri gösterilmiștir. Magnitüd bandının bir fonksiyonu olarak depremsellik oran değişimlerinin zamanları, düşüşler için kırmızı renkte artışlar içinse mavi renkte \% 99 güven seviyesinde verilmiştir.

Deprem aktivitesinin bölgesel ve zamana bağlı değişimlerinin analizi edilmesi ile gerek Türkiye gerekse dünyanın farklı birçok bölgesi için deprem istatistiği çalışmaları bir ivme kazanmıştır. Ülkemizde özellikle 17 Ağustos 1999 İzmit $(\mathrm{Mw}=7.4)$ ve 12 Kasım 1999 (Mw=7.2) depremleri ile birlikte Türkiye'nin farklı birçok bölgesi için deprem tehlikesi üzerine yapılan çalışmalar atış göstermiştir. Depremlerin olma potansiyeli ve olası yerlerinin doğru olarak tahmin edilebilmesi için istatistiksel analizlerde kullanılan veri sayısı oldukça önemlidir. Dolayısıyla, depremsellik çalışmalarında daha güvenilir sonuçların elde edilebilmesi için maksimum veri sayısının kullanılmasına ve buda istasyon sayısının artmasıyla birlikte küçük depremlerin daha fazla kayıt edilmesine bağlıdır. Ülkemizde, özellikle 2000'li yıllardan sonra istasyon sayısındaki artışla birlikte daha fazla küçük deprem kaydedilmeye başlanmış ve buda deprem istatistiği üzerine yapılan çalışmaları olumlu yönde etkilemiştir. Gümüşhane ili tektonik ve depremsellik açısından tehlikeli bir bölge olmamasına karşın, Türkiye'nin en aktif doğrultu atımlı fay zonlarından biri olan Kuzey Anadolu Fay Zonuna olan yakınlığ nedeniyle bu civarda oluşabilecek büyük depremlerden etkilenme potansiyeli olan bir bölgedir. Sonuç olarak, Gümüşhane ve civarındaki deprem istatistiği çalışmaları deprem sayısının son yıllarda artış göstermesi ile daha güvenilir bir şekilde yapılmıştır.

\section{Sonuçlar}

Bu çalışmada, Gümüşhane ve civarında 2016 yılı ortalarındaki güncel deprem aktivitesinin bölgesel ve zamana bağlı olarak istatistiksel bir analizi yapılmış ve deprem tehlikesi açısından bölgesel ve zamana bağlı olarak değerlendirilmiştir. $\mathrm{Bu}$ kapsamda, sismotektonik $b$-değeri, sismik durgunluk $Z$ değeri, tamlık magnitüdü $M c$-değeri, depremlerin bölge-zaman-magnitüd dağılımları, deprem oluşma olasılıkları ve tekrarlama zamanları gibi birçok istatistiksel parametre kullanılmıştır. İstatistiksel analizler ZMAP tekniği kullanılarak yapılmıştır. Deprem kataloğu Boğaziçi Üniversitesi KRDAE'den temin edilmiştir. Katalog süre magnitüdü $M_{\mathrm{D}}$ 'ye göre homojendir ve 21 Eylül 1970-26 Haziran 2016 yılları arasında 45.76 yıllık bir zaman periyodunda $M_{\mathrm{D}} \geq 1.1$ olan 2500 depremi içermektedir.

Gümüşhane ve civarındaki depremsellik 2003-2011 yılları arasında önemli bir artış gösterirken 2011 yılında tekrar bir azalım sürecine girmiştir. Deprem oluşumları genellikle 2.5-3.5 magnitüd aralığında 
değişim gösterirken 2.8 civarında bir maksimuma sahiptir. Gümüșhane ve civarı için tamlık magnitüdü $M c=2.8$ olarak alınmış ve Gutenberg-Richter ilişkisindeki $b$-değeri $1.01 \pm 0.02$ olarak hesaplanmıştır. $\mathrm{Bu}$ değer tektonik depremler için ortalama $b=1.0$ ile verilen Gutenberg-Richter ilişkisi ile çok iyi temsil edilir. $b$-değeri zaman içerisinde ana şok oluşumlarından önce önemli azalımlar göstermekle birlikte son yıllarda önemli bir düşüş söz konuş değildir. Düşük $b$-değerleri $(<0.9)$ Kelkit ve Köse'yi içine alan doğu ve kuzey doğu kısımlar ile Köse'nin kuzeyinde ve Kelkit'in güneyinde gözlenmiştir ve düşük $b$-değerlerinin gözlendiği bu bölgeler gelecekteki olası deprem tehlikesi açısından önem arz etmektedir. Belirli magnitüd seviyeleri için deprem oluşumlarının tekrarlama zamanları ve olasılıkları üzerine yapılan analizler, Gümüşhane ve civarının bölge için büyük sayılabilecek deprem oluşumları açısından kısa vadede önemli bir deprem tehlikesi potansiyeline sahip olmadığını ortaya koymaktadır. Depremsellik oran değişimlerinin hesabı için $M_{\mathrm{D}} \geq 2.8$ olan ve 1336 depremi içeren ayrıştırılmış deprem kataloğu kullanılmıştır. Gümüşhane ve civarında 2016 yılı ortalarında herhangi bir öncü durgunluk anomalisi gözlenmemiştir ve buda, güncel depremsellik oranında önemli bir sismik durgunluğun olmadığını ortaya koyar. Sonuç olarak istatistiksel analizler, Gümüşhane sınırları içerisinde kısa vadede önemli bir deprem potansiyelinin olmadığını ortaya koyar.

\section{Teșekkür}

İstatistiksel analizler için ZMAP yazılımını sağlayan Prof. Dr. Stefan Wiemer'e ve yapıcı katkılarından dolayı hakem kuruluna teşekkürlerimi sunarım. Ayrıca deprem kataloğunu temin etmemde yardımcı olan Boğaziçi Üniversitesi KRADE'ye teşekkür ederim.

\section{Kaynaklar}

Aki, K., 1965. Maximum likelihood estimate of $\mathrm{b}$ in the formula $\log N=a-b M$ and its confidence limits, Bulletin of the
Earthquake Research Institute, Tokyo University, 43, 237-239.

Arabasz, W. J. ve Hill, S. J., 1996. Applying Reasenberg's cluster analysis algorithm to regional earthquake catalogs outside California (abstract), Seismological Research Letters, 67(2), p. 30.

Arabasz, W. J. ve Wyss, M., 1996. Significant precursory seismic quiescence in the extensional Wasatch front region Utah, EOS Trans. AGU 77, F455.

Awad, H., Mekkavi, M., Hassib, G. ve Elbohoty, M., 2005. Temporal and three dimensional spatial analysis of seismicity in the Lake Aswan area, Egypt, Acta Geophysica Polonica 53(2), 152-166.

Bayrak, Y., Öztürk, S., Çınar, H., Kalafat, D., Tsapanos, T. M., Koravos, G. Ch. ve Leventakis, G. A., 2009. Estimating earthquake hazard parameters from instrumental data for different regions in and around Turkey, Engineering Geology, 105, 200-210.

Bozkurt, E., 2001. Neotectonics of Turkey-a synthesis, Geodinamica Acta, 14, 3-30.

Chouliaras, G. ve Stavrakakis, G. N., 2001. Current seismic quiescence in Greece: Implications for seismic hazard, Journal of Seismology, 5, 595-608.

Console, R., Montuori, C. ve Murru, M., 2000. Statistical assessment of seismicity patterns in Italy: Are they precursors of subsequent events?, Journal of Seismology, 4, 435-449.

Frohlich, C. ve Davis, S., 1993. Teleseismic b-values: Or, much ado about 1.0, Journal of Geophysical Research, 98(B1), 631-644.

Gutenberg, B. ve Richter, C. F., 1944. Frequency of earthquakes in California, 
Bulletin of the Seismological Society of America, 34, 185-188.

Habermann, R. E., 1983. Teleseismic detection in the Aleutian Island arc, Journal of Geophysical Research, 88 (B6), 5056-5064.

Katsumata, K. ve Kasahara, M., 1999. Precursory seismic quiescence before the 1994 Kurile earthquake $(\mathrm{Mw}=8.3)$ revealed by three independent seismic catalogs, Pure Applied Geophysics, 155, 443-470.

Ormeni, R., Öztürk, S. ve Gjuzi, O., 2016. Regional and temporal evaluation of seismicity in the Vlora-Elbasani-Dibra Transversal Fault Zone, Albania, 3rd International Balkans on Challenges of Civil Engineering, 3-BCCCE, 10-20 pp., Tirana, Albania.

Öncel, A. O. ve Wilson, T. H., 2007. Anomalous seismicity preceding the 1999 Izmit event, NW Turkey, Geophysical Journal International, 169 (1), 259-270.

Öztürk, S., Bayrak, Y., Çınar, H., Koravos, G. Ch. ve Tsapanos, T. M., 2008. A quantitative appraisal of earthquake hazard parameters computed from Gumbel I method for different regions in and around Turkey, Natural Hazards, 47, 471-495.

Öztürk, S., 2009. An application of the earthquake hazard and aftershock probability evaluation methods to Turkey earthquakes, PhD Thesis, Karadeniz Technical University, Trabzon, 346 pp (in Turkish with English abstract).

Öztürk, S., 2011. Characteristics of Seismic Activity in the Western, Central and Eastern Parts of the North Anatolian Fault Zone, Turkey: Temporal and Spatial Analysis, Acta Geophysica, 59(2), 209-238.
Öztürk, S. ve Bayrak, Y., 2012. Spatial variations of precursory seismic quiescence observed in recent years in the eastern part of Turkey, Acta Geophysica, 60 (1), 92-118.

Öztürk, S. ve Sarı, M., 2013. Forecasting the location of future earthquakes based on the Pattern Informatics in the Western Anatolian Part of Turkey, 7th Congress of Balkan Geophysical Society, 18626, Tirana, Albania.

Öztürk, S., 2014. Türkiye'nin Batı Anadolu bölgesi için deprem istatistiği ve olası güçlü depremlerin orta vadede bölgesel olarak tahmini üzerine bir çalışma, Gümüșhane Üniversitesi Fen Bilimleri Enstitüsü Dergisi, 4(1), 75-93

Öztürk, S., 2015a. Fractal Dimension of Seismicity and a Modeling on the Intermediate-Term Forecasting for the Locations of Expected Strong Earthquakes: Eastern Anatolian Region, Turkey, Gümüsshane University Journal of Science and Technology Institute, $5(1), 1-23$.

Öztürk, S., 2015b. A study on the correlations between seismotectonic $b$-value and $D c$-value, and seismic quiescence $Z$ value in the Western Anatolian region of Turkey, Austrian Journal of Earth Sciences, 108 (2), 172-184.

Polat, O., Gok, E. ve Y1lmaz, D., 2008. Earthquake hazard of the Aegean Extension region (West Turkey), Turkish Journal of Earth Sciences, 17, 593-614.

Reasenberg, P. A., 1985. Second-order moment of Central California seismicity, 1969-1982, Journal of Geophysical Research, 90 (B7), 54795495.

Reilinger, R. E., McClusky, S. C., Oral, M.B., King, W. ve Toksöz, M. N., 1997. Global Positioning System measurements of present-day crustal 
movements in the Arabian-AfricaEurasia plate collision zone. Journal of Geophysical Research, 102, 9983-9999.

Şaroğlu, F., Emre, O. ve Kuşcu, O., 1992. Active fault map of Turkey, General Directorate of Mineral Research and Exploration, Ankara, Turkey.

Taş, N., Okumuş, E., Öner, Ş., Köksal, C., İcat, M. Y., Tanış, S. ve Aslan, N., 2003. Gümüşhane il çevre durum raporu, 179 sayfa, Gümüşhane Valiliği İl Çevre ve Orman Müdürlüğü, Gümüşhane.

Utsu, T., 1971. Aftershock and earthquake statistic (III): Analyses of the distribution of earthquakes in magnitude, time and space with special consideration to clustering characteristics of earthquake occurrence (1). Journal of Faculty of Science, Hokkaido University, Series VII (Geophysics), 3, 379-441.

Wiemer, S. ve Wyss, M., 1994. Seismic quiescence before the Landers $(\mathrm{M}=7.5)$ and Big Bear $(\mathrm{M}=6.5) 1992$ earthquakes, Bulletin of the Seismological Society of America, 84, 3, 900-916.
Wiemer, S. ve Wyss, M., 2000. Minimum magnitude of completeness in earthquake catalogs: Examples from Alaska, the Western United States, and Japan, Bulletin of the Seismological Society of America, 90(3), 859-869.

Wiemer, S., 2001. A software package to analyze seismicity: ZMAP, Seismological Research Letters, 72, 3, 373-382.

Wu, Y. M. ve Chiao, Y. L., 2006. Seismic quiescence before yhe 1999 Chi-Chi, Taiwan, $M_{w} 7.6$ earthquake, Bulletin of the Seismological Society of America, $96,1,321-327$.

Wyss, M., 1997. Nomination of seismic quiescence as a significant precursor, Pageoph, 149(1), 3-16. 